2000

\title{
A Preliminary Assessment of the New Home Seller Capital Gains Law
}

Thomas Bier

Cleveland State University, t.bier@csuohio.edu

Ivan Maric

Winifred Weizer

Cleveland State University, w.weizer@csuohio.edu

Follow this and additional works at: https://engagedscholarship.csuohio.edu/urban_facpub

Part of the Urban Studies and Planning Commons

How does access to this work benefit you? Let us know!

\section{Repository Citation}

Bier, Thomas; Maric, Ivan; and Weizer, Winifred, "A Preliminary Assessment of the New Home Seller Capital Gains Law" (2000). All Maxine Goodman Levin School of Urban Affairs Publications. 012326. https://engagedscholarship.csuohio.edu/urban_facpub/26

This Report is brought to you for free and open access by the Maxine Goodman Levin School of Urban Affairs at EngagedScholarship@CSU. It has been accepted for inclusion in All Maxine Goodman Levin School of Urban Affairs Publications by an authorized administrator of EngagedScholarship@CSU. For more information, please contact library.es@csuohio.edu. 
A Preliminary Assessment of the New Home Seller Capital Gains Law

Tom Bier, Ivan Maric, and Winifred Weizer

Housing Policy Debate, vol. 11, issue 3

Fannie Mae Foundation 2000

\begin{abstract}
In August 1997, the capital gains law was changed to enable most sellers to move down in price without incurring a tax liability. The previous law was critiqued as detrimental to cities by promoting out-migration to higher-priced homes; it was asserted that the requirement that sellers buy a home equal to or greater than the value of the one they sold to defer tax liability obstructed movement down in price. This study asked whether movement down in price increased in four Ohio cities after the law was changed and whether movement out of the central cities decreased and movement in from the suburbs increased.

Statistically significant change in movement down was found in only one city. Movement up in price and outward dominated all four areas. The study produced no direct evidence of the factors that influenced seller-buyer move decisions. The process of life-course change-younger households moving up to larger, move expensive homes and older households moving down to smaller, less expensive properties-was probably the driving force.
\end{abstract}

